\title{
Quo vadis, avagy \\ a nemzetgazdaság \\ és társadalom fejlődésének \\ stratégiai kérdései
}

\section{Quo Vadis: The Strategic Issues \\ of the Development of the National Economy and Society}

\section{Összefoglalás}

A kutatási beszámoló elsô részében makrogazdasági és átfogó társadalmi válságok vázlatos áttekintését tehette meg az olvasó a Polgári Szemle elôzó számában. A nemzetközi politikai gazdaságtan egyik elmélete, az új medievalizmus megoldásként tekint a nem kormányzati, civil szereplőkre. Jelen részben a civil, nonprofit szektor magyarországi fejlôdése és mai állapota kerül a vizsgálódás középpontjába.

Journal of Economic Literature (JEL) kódok: L3, D6, B2

Kulcsszavak: civil szervezetek, társadalmi tôke, új medievalizmus

Szablics BÁlint, PhD-hallgató, Nemzeti Közszolgálati Egyetem, Állam és ökonómia kutatási terület (szablicsbalint@t-online.hu). 


\section{Summary}

In the first part a macroeconomic approach was used while introducing structural changes and is observing the social impact of our lately challenges. A narrow pathway of disentanglement is glimmering as the reader comes to the second piece. New medievalism is focusing on NGOs as a possible means of solution. Thus a deeper study of Hungarian NGO sector has to be done to evaluate the potential lying in these special pieces of our society.

Journal of Economic Literature (JEL) codes: L3, D6, B2

Keywords: civil society, social capital, new medievalism

\section{A CIVIL SZERVEZETEK ÉS SZEREPÜK A VERSENYKÉPESSÉGBEN}

A szociális ellátások fejlōdése - a civilség bölcsôje Magyarországon

A magyarországi civil szektor történetét, mai formája kialakulásának történelmi elốzményeit kutatók az államalapításig vezetik vissza. A jótékonyság, az elesettek segítése intézményesült formát öltött már a kezdeti, államalapítást követő idôkben, az állami szervezet és az egyház felismeréséból kiindulva. Történelmünk során számos példa mutatja, hogy ha nem is mindig reflektorfényben, de alakult, változott, fejlôdött a mai értelemben vett civil társadalom.

A szociális ellátások gyakorlati megvalósítójaként az egyház szerepe már a kezdetektôl kiemelkedô volt. Emellett a tehetôsebbek magánvagyonukból is áldoztak jótékony célra, az önsegítésnek számos formája alakult ki. Mária Terézia 1775-ben hozott létre saját vagyonából árva gyermekeket segító alapítványt (Kuti, 1998).

Számos egyéb polgári kezdeményezés az 1867 utáni korszakra tehetô: a gyermekek segítésére 1871-ben létrejött Frôbel Nóegylet, a Pesti Bölcsôde Egylet, az 1876-ban létrehozott Hajléktalanok Menhelye Egyesület, az 1886-os alapítású Szegény Beteg Gyermekek Egyesülete. A kiegyezésig tartó idôszakban a közigazgatás szociális ellátásokról való gondolkodásának középpontjában a szegények megsegítése állt, azonban az, hogy ennek állami, egyházi vagy társadalmi feladatnak kell lennie, nem volt egyértelmú. Az 1871-es elsô magyar szegénytörvény a szegényügyet az illetôségi község teendői közé sorolta, ${ }^{1}$ amelynek eredményeként a szegény embereknek a születési hely szerinti községhez kellett fordulnia segélyezésért. A társadalom szociális gondjainak fokozódásával egyre professzionálisabbá váltak a szociális szolgáltatások, tudatos szakmafejlesztés valósult meg pl. a gyermekvédelem terén. Az igények változása, a szakmai és jogi fejlôdés 1920-ra a Népjóléti Minisztérium felállítását eredményezte. ${ }^{2}$ 1927-ben megszületett az elsố társadalombiztosítási törvény³ is, amely az ipari munkások betegségi, baleseti, öregségi biztosítását rendezte. Szintén ebben az évben indult az Egri Norma néven bevezetett, szegénygondozást segítő rendszer, amelyet 1936-ban országos szintre emeltek. 
Szablics Bálint: Quo vadis, avagy a nemzetgazdaság és társadalom fejlödésének...

A második világháború traumája és a fentebb említett körülmények a háború után minden korábbinál nagyobb társadalmi-szociális kihívás elé állították az államot. A Népjóléti Minisztérium (újra)alapítását a rossz egészségügyi, anyagellátási helyzettel és a hadigondozási feladatok nagy számával indokolták, feladata a szociális és egészségügy irányítása lett. A minisztériumot 1945 és 1947 között Molnár Erik, az 1947-1948-as időszakban Olt Károly, majd 1949-tôl 1950-ig a népesedési politikájáról is közismert Ratkó Anna vezette.

A szociálpolitika intézményes alapjait és új szervezetrendszerét már 1945-ben kialakították, állami feladatként elismerve a dolgozók helyzetének javítását. Az intézkedés nyomán a városok szintjéig elért a szociális igazgatás intézményrendszere. Ezzel, a szociális társadalom nézetének megfelelóen, a szociális problémákat is felszámolták, ez azonban csak az ideológiának való megfelelést szolgálva, valódi problémákat takart el. Az ötvenes években kialakult - máig tartó hatású - szemlélet szerint az egyén, nem ismerve a költségvetés nagyságrendjeit, tulajdonképpen ajándékként értelmezte ezeket a juttatásokat. A megtermelt jövedelmeket terhelő nagyarányú elvonás és a szociális kiadások egyre nagyobb mértéke, a kiadási oldal ellenőrizhetetlensége ellenére is, a társadalom elfogadta a relatív jólétet és az elesett helyzetbe kerülés veszélyeztetettsége esetére a kompenzálás bizonytalan ígéretét.

1. táblázat: A szociális biztonságra fordított kiadások Magyarországon 1950 és 1990 között (milliárd forint)

\begin{tabular}{l|c|c|c|c|c}
\hline \multicolumn{1}{c|}{ Kiadás } & $\mathbf{1 9 5 0}$ & $\mathbf{1 9 6 0}$ & $\mathbf{1 9 7 0}$ & $\mathbf{1 9 8 0}$ & \multicolumn{1}{c}{$\mathbf{1 9 9 0}$} \\
\hline Táppénz & 0,249 & 1,656 & 3,750 & 8,534 & 21,4 \\
\hline Munkanélküli-ellátás & \multicolumn{1}{c|}{-} & - & - & - & 0,8 \\
\hline Nyugdíjellátások & 0,927 & 4,427 & 12,985 & 55,979 & 156,4 \\
\hline Családi pótlék & 0,303 & 1,391 & 2,810 & 13,561 & 52,8 \\
\hline Anyasági juttatások & 0,070 & 0,179 & 1,952 & 5,808 & 15,1 \\
\hline Egészségügyi ellátás & 0,595 & 3,782 & 8,329 & 17,800 & 71,0 \\
\hline Összesen (A) & 2,144 & 11,435 & 29,826 & 101,68 & 317,5 \\
\hline GDP (B) & 55,8 & 196,7 & 332,3 & 718,5 & 1722,8 \\
\hline (A)/(B)x100 & 3,8 & 5,8 & 8,9 & 14,2 & 18,4 \\
\hline
\end{tabular}

Forrás: Tomka, 2003

A szegényparasztság jelentôs része tulajdonhoz és megélhetéshez jutott a szintén az 1945. évhez kötôdô földreformmal. Ezzel párhuzamosan indult meg az államosítás is, amely bázisát képezte a teljes foglalkoztatást biztosító gazdaság kialakításának. A kapitalista országokhoz képest nagyobb súllyal képzelték el a szükségletek kollektív kielégítését, természetesen nem piaci alapon. Ezzel összhangban alacsony bérszínvonal alakult ki, amelyen felül az állam által felvállalt oktatási, egészségügyi szolgáltatások igénybevételére volt lehetôség. A kollektív szükségletek mellett az állam terjeszkedésének eredményeként számos egyéni szükséglet (pl. alapvető élelmiszerek) kielégítése, finanszírozása is közfeladattá vált. Az elképzelésekból - részben az állam anyagi lehetôségeinek 
korlátai miatt - kevés valósult meg, a diktatórikus politikai fordulat alapvetôen befolyásolta a szociálpolitika eszköztárát. A tervgazdálkodás kialakítása során még az is felmerült, hogy önálló szociálpolitikára nincsen szükség, hiszen „a népi demokrácia minden tette szociálpolitika”. ${ }^{4}$ E felfogás a Népjóléti Minisztérium 1950-es megszüntetéséhez vezetett, a szociális szakszolgálatokat pedig felszámolták. A szociálpolitikát - egy egyébként is társadalmi sebekkel terhelt idôszakban - alárendelték a hatalom ideológiai érdekeinek. Kizárólag a dolgozókra, a munkásságra fókuszáltak, a társadalombiztosítás és munkavédelem területét a szakszervezetek kapták meg. Minden más terület gyakorlatilag elsorvadt. Az ideológia érdekeinek megfelelő, szociálisnak mondható célok, mint a munkahelyteremtés és a nók munkába állítása, és ennek érdekében a gyermekeket ellátó intézmények támogatása, tudtak érvényesülni. De ez egyben azt is eredményezte, hogy az e körön kívül esố rétegek diszkriminációja mindjobban felerôsödött. Emellett egyes intézkedések még ezen a körön belül is különbségeket erôsítettek: a parasztságot kizárták az egészségügy ingyenességéból, az állami alkalmazottak privilegizált juttatásokban részesültek. Minden intézkedés abba a fentebb említett irányba hatott, hogy az igénybevevôk az állam, a párt ajándékaként tekintsenek a szociális ellátás keretében kapott juttatásokra, és semmiképp ne alapvető jogként.

Az elkobzott vagyon szerzetesrendnek való adományozásától az egyházi tized „negyedelésén”, a második budai kórház megalapításán, a Szent György Társulaton át a céhek mellett múködő segélypénztárokig számos konkrét példa mutatja a változatos formákat, amelyek az elmúlt ezer évben kialakultak és elterjedtek. Természetesen a fejlődés üteme nem mindig volt dinamikus, nem feltétlenül követte az európai trendeket, így pl. a török hódoltság vagy a Habsburg-megszállás idején a 17-18. században, míg a második világháborút követôen, a 20. században is jellemzó volt az elnyomó hatalom ellenérdekeltsége az önszervezôdések kialakulásában, fennmaradásában. Ezen idôszakokat azonban számban, formagazdagságban és motivációban is fellendülés követte (Kuti, 1998).

\section{Definíciós vita - „Hivjuk talán nonprofitnak”}

Hogy kik is azok a nonprofit szervezetek? E kérdésben hosszas szakmai viták folytak Magyarországon is, hiszen a kifejezés nem definiált módon vált életünk részévé, hanem már létezó jogintézmények összefoglaló neveként kezdtük alkalmazni. ${ }^{4}$ A definíciós vitáról a téma nemzetközileg is elismert szakértői, Kuti Éva és Marschall Miklós 1991-ben írtak összefoglaló tanulmányt (Kuti-Marschall, 1991), amelyben megkísérelték szintetizálni a nemzetközi gyakorlatban is eltérô tartalmú fogalom közös ismérveit. E szerint a nonprofit szektor általánosan elfogadott definíciója, az alkotó szervezetek közös jellemzői alapján, az alábbi ismérvekból vezethetô le:

- a profit felosztása tilos (tehát nem a nyereség megszerzése, hanem annak tulajdonosok/tagok közötti szétosztása);

- végrehajtó hatalomtól, kormányzattól való függetlenség;

- szervezett múködés, amely jogi személyiségben is megtestesül (vö. Sipos, 2003:271-272). 
Szablics Bálint: Quo vadis, avagy a nemzetgazdaság és társadalom fejlödésének...

A mai jogszabályok alapján nonprofit szektorba tartozónak tekintjük a civil szervezeteket (civil társaság, egyesület, alapítvány, közalapítvány) és a nonprofit gazdasági társaságokat ${ }^{5}$ (korábban közhasznú társaság).

Kuti és Marschall fent hivatkozott tanulmányában is elismeri ugyanakkor, hogy a definícióból több olyan további elem kimaradt, amely más, a területen nagyobb (és főképp törésektôl mentes) múlttal rendelkezô országokban szintén a meghatározás fontos részei. Ilyenek lehetnek pl. a közjó szolgálata és az elsôdlegesen adományokból származó bevétel, továbbá a pártpolitikától, valamint a hitéleti tevékenységtôl való mentesség. Véleményem szerint azonban ezen distinkciók valóban nem illeszthetôk teljes egészében a hazai joganyagban szabályozott fogalmakhoz.

\section{Müködési jellemzők}

A magyarországi civil szektor múködési problémáinak kezelésével kapcsolatos egyik legalapvetőbb probléma, hogy a szektor valódi méretérôl meglehetôsen ellentmondásos adatok állnak rendelkezésre. Ennek egyik oka az, hogy a jogszabályok 2012 elôtti állapota nem kezelte kellôképp azt a meglehetôsen életszerú helyzetet, hogy egy közösség, egy szervezet a tevékenységét objektív (pl. a létesítő okiratban meghatározott cél teljesülése; tagok, alapítók, legfóbb szerv tagjai megszúnése, halála) vagy szubjektív (pl. az egyesület tagjai nem kívánnak tovább tagok lenni, és tagsági jogviszonyukat megszüntetik, ezzel kiüresítve az egyesületet) okok miatt megszúnik. Ehhez a kellố eszközök nem álltak rendelkezésre, a szervezetek megszüntetésére a legváltozatosabb, kreatív technikák alakultak ki, végsố soron pedig ahhoz vezettek, hogy motiváció, illetve intézkedésre jogosult hiányában a szervezetek „bennragadtak” a nyilvántartásban. Számokban kifejezve: a bírósági nyilvántartásban mintegy 80 ezer, ${ }^{6}$ a hivatalos statisztikában csaknem 128 ezer, ${ }^{7}$ az éves - a szervezetek önbevallásán múló - statisztikai adatfelvétel során pedig 64 ezer kimutatott nonprofit szervezet (Tokaji, 2016) volt.

A helyzet áttekintését nehezítô másik kiemelkedô körülmény, hogy a különbözô hivatalos forrásokból rendelkezésre álló adatok eltérô tartalommal bírnak, amelynek részben szakmai, részben pedig technológiai okai vannak. A statisztikai oldalon a fenti bírósági adatokkal való összehasonlíthatóság akadályát az okozza, hogy a KSH által használt „nonprofit szervezet” mint kategória nem ugyanazon szervezettípusokat tartalmazza, ${ }^{8}$ mint az OBH Civil Szervezetek Névjegyzéke elnevezésú közhiteles nyilvántartása. Ráadásul az OBH adatbázisa a közhiteles törvényszéki nyilvántartásokból táplálkozik, míg a KSH adatfelvételból származó adatai csak azon szervezetekrôl adnak információt, amelyek az éves kérdőívet visszaküldték, és a feldolgozás időigénye miatt kétéves késleltetéssel is számolni kell.

Mindezekkel együtt is abból a feltételezésból kiindulva, hogy az a szervezet tekinthetô múködônek, amely adatot szolgáltat magáról az adatfelvétel során (pl. KSH éves adatfelvétele), és hogy a szervezetek száma már nem változik dinamikusan, a KSH kétéves késleltetésú, adatfelvételból származó adatait szokta a szakma hiteles, a valósághoz közeliként elismerni. 


\section{1. ábra: A nonprofit szervezetek számának változása}

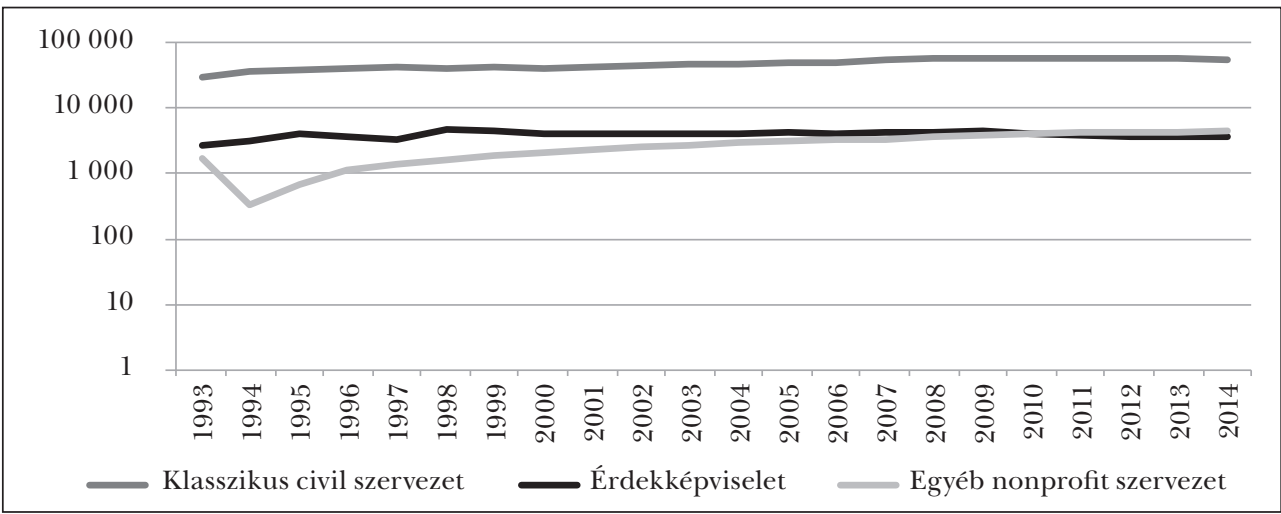

Forrás: $K S H$

Számunkra azonban a nonprofit szervezetek közül csak a „klasszikus civil szektor”, az alapítványok (magánalapítványok) és egyesületek érdekesek (2. ábra).

2. ábra: A nonprofit szervezetek száma, bevételei, költségei, eredménye jogi forma szerint

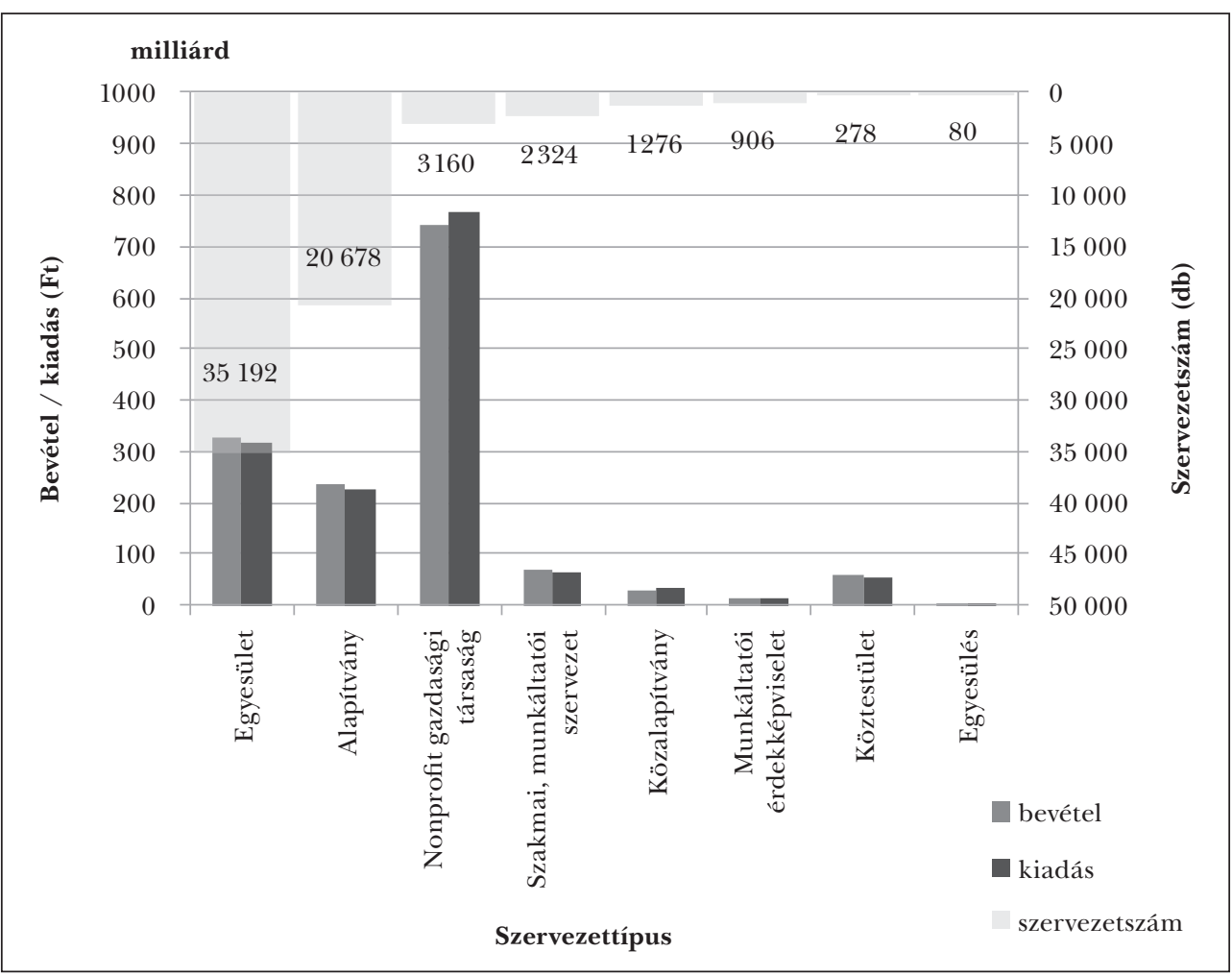

Forrás: $K S H$ 
Szablics Bálint: Quo vadis, avagy a nemzetgazdaság és társadalom fejlódésének...

A különbségtétel azért nagyon fontos, mert a foglalkoztatási, bevételi adatok tekintetében azonnal látható a különbség, tetten érhetô a torzító hatás, amely indokolja a nonprofit szervezetek és a civil szervezetek közötti különbségtételt (3. ábra).

3. ábra: A civil szervezetek részesedése a nonprofit szektorra vonatkozó adatok arányában

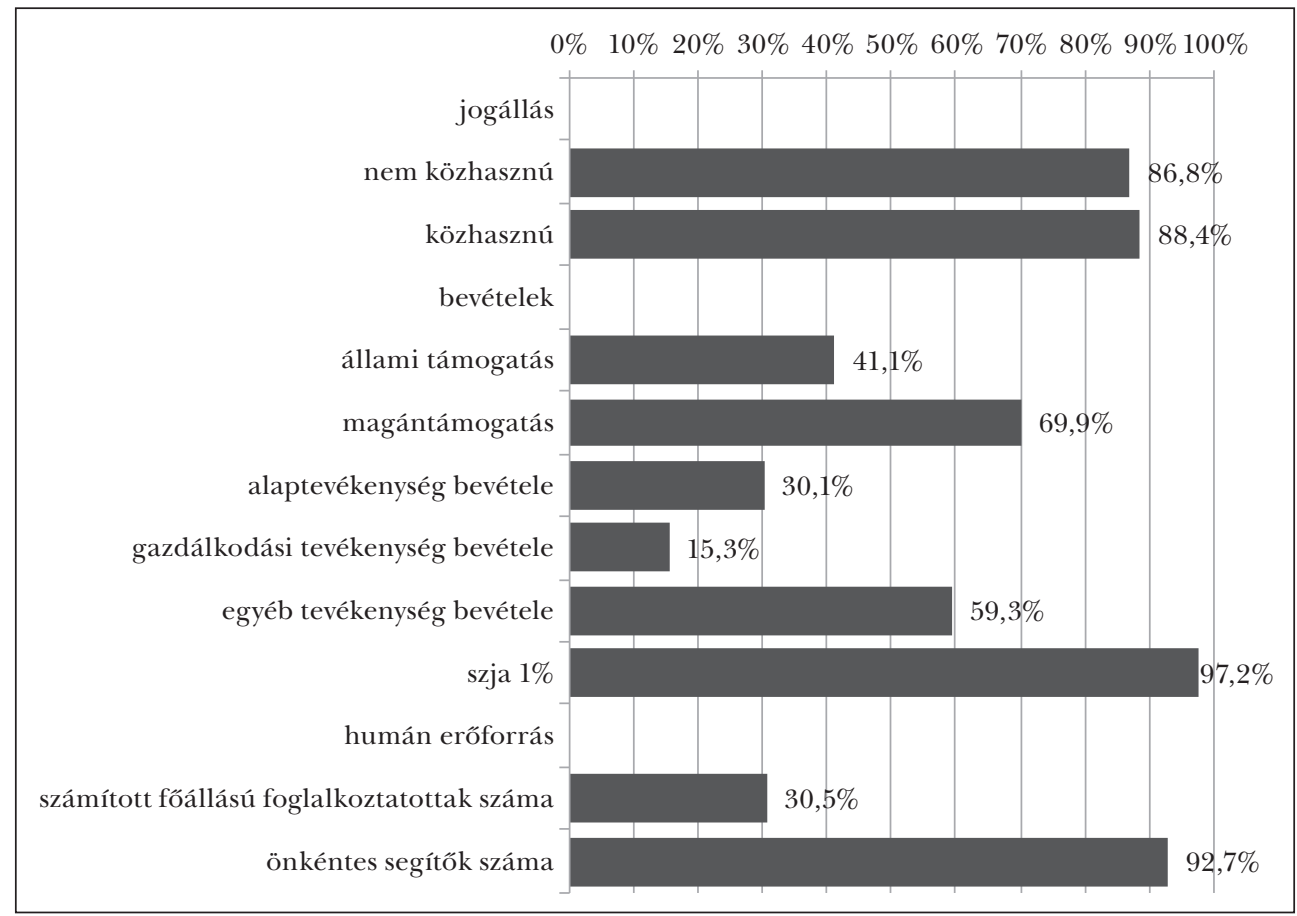

Forrás: KSH

A fentiekból következô megállapítás, hogy bár a statisztika a nonprofit és civil szervezeteket egyben kezeli, a teljes nonprofit szektoron belül a civil szervezetek alkotják a túlnyomó többséget $(87,4 \%)$, ugyanakkor az összes fizetett alkalmazottnak kevesebb mint egyharmadát (30,5\%), míg az önkéntesek ${ }^{9}$ szinte teljes létszámát (92,7\%-át) foglalkoztatja. Ezzel egy idóben a teljes bevételnek csak 38\%-ából gazdálkodik, és végzi tevékenységét. Abszolút számokban kifejezve e mutatók a következók szerint alakultak a 2014. évben: civil szervezetek száma 55870 db, fizetett alkalmazottaik száma 37 462 fô (számított fóállású foglalkoztatott), önkéntesek száma 466992 fó, éves bevétel 558549,5 millió Ft (Tokaji, 2016). ${ }^{10}$

\section{Változások a rendszerváltozást követôen}

Kétségtelenül igen jelentôs, szimbolikus tartalmú volt a rendszerváltónak mondott törvények sorában előkelő helyet elfoglaló 1989. évi II. törvény az egyesülési jogról, a civil szervezetek múködésérôl és támogatásáról (Etv.). Ez a jogszabály teremtette, 
nyitotta meg újra az egyesületek (társadalmi szervezetek) létrehozásának szabadságát. Bár az Etv. számos ponton nem teremtett tiszta helyzetet, a rendszerváltozás pillanatában a megfelelố eszközzel élve nyitott régi-új utakat az állampolgárok számára. E lehetôséggel az állampolgárok éltek is, és a következô években rendkívüli mértékú alapítási kedv eredményezett számtalan új szervezetet.

Újabb impulzust adtak a 90-es évek közepén kiharcolt, illetve megalkotott jogszabályok, amelyek innovatív megközelítéssel, esetenként nemzetközileg is egyedülálló megoldásokkal segítették a szervezetek múködtetését: az adókedvezmények szélesítését az szja 1\%-os rendszerének bevezetése, majd pedig a közhasznúsággal kapcsolatos jogszabály követte.

Az ezredfordulót követô évekig a jogszabályokkal kapcsolatos fejlesztési munka a háttérben zajlott, a területtel foglalkozó minisztériumok a meglévô eszközök felhasználásával, szakmafejlesztési koncepciók kidolgozásával és eredményes végrehajtásával (pl. tájékoztató honlap létrehozása, civil házak hálózatának kiépítése, képzési és kutatási programok fejlesztése, lebonyolítása), intenzív munkával alapozták meg a továbblépést.

A következô idôszakot már stratégiai gondolkodás, tervezett múködés jellemezte a kormányzat részérôl, és bár az adókedvezmények rendszerében a civil szektor számára kedvezôtlen változások következtek be az állam finanszírozási gondjainak kezelése miatt, létrejött a demokratikus alapokon nyugvó Nemzeti Civil Alapprogram és az önkéntes munkát elismerố jogi környezet.

A két évtizedes jogfejlôdés során végig jellemzô volt, hogy az újabb jogszabályok a korábbiakra épülve, de azzal nem mindig szerves egységben szabályoztak egy-egy újabb területet több vagy éppen kevesebb sikerrel. Szakértôk egy csoportja 2005 folyamán érdekes próbának, kísérletnek vetette alá a civil szervezetek nyilvántartásával foglalkozó megyei bíróságokat: lényegében azonos alapszabállyal egy idôben kezdeményezték minden megyében és a fốvárosban egy-egy egyesület nyilvántartásba vételét. A megdöbbentô eredményt egy kiadványban foglalták össze: nem volt két egyforma eset, ahol ugyanannyi idố alatt vagy ugyanazzal a tartalommal reagált a bíróság az eljárás során. A felmérés rávilágított egy fontos problémára, amely alapján a jelentôsen eltérô bírói gyakorlatból a jogszabályok nem megfelelô minôségére lehetett következtetni, a jogszabályok felülvizsgálata elodázhatatlanná vált (Fülöp, 2006).

Emellett az eltelt két évtizedben nemcsak a jogszabályok, hanem a társadalmi környezet, elvárások és igények is változtak, amelyek újabb gondolkodást indítottak el a jogalkotóban, ezért született meg a civil törvény koncepciója, és kezdődött meg 2010ben a társadalmi egyeztetésekkel kísért elôkészítése. A 2011 folyamán elôkészített és az év végén elfogadott, majd 2012-ben hatályba lépett szabályok számos területen megújították, másokon összhangot teremtettek, de új innovatív - a civil szervezetek által régóta hangoztatott és igényelt - eszközök (pl. országos közhiteles nyilvántartás, egykapus ügyintézés, civil társaság, iratminták stb.) is a jogszabályba kerültek.

\section{A társadalmi tôke szerepe}

A versenyképesség egyik fontos tényezőjének tekintett társadalmi tôke elméleti alapját Francis Fukuyama dolgozta ki. Munkájának középpontjában a bizalom mint a gazda- 
Szablics Bálint: Quo vadis, avagy a nemzetgazdaság és társadalom fejlödésének...

ság egyik fó mozgatórugója áll. Jelenti ez azt, hogy a gazdasági kapcsolatok csak olyan környezetben tudnak létrejönni, amelyben a felek megbíznak egymásban. Egy ország teljesítménye szempontjából pedig rendkívül fontos, hogy annak intézményeiben, a politikai és végrehajtó hatalom gyakorlóiban is megbízzanak. Különböző kultúrákban mindez másként érvényesül: a Távol-Keleten például alapvetôen a család kerül elôtérbe (az uralkodó után), míg európai és fejlettnek mondott nyugati társadalmainkban inkább a liberális gazdasági kapcsolatok élveznek prioritást. És - sajnálatos módon egyre inkább elmondható, hogy társadalmi hálózatainkban az individualizmus erôsödése egyre inkább nehezíti a közösségek kialakulását, fejlődését, miközben a technológiai újítások látszatközösségeket teremtenek. Ezzel kommercializálják a közösséget, ${ }^{11}$ áruvá teszik, tartalmuk kiüresedik. Az információs társadalom fejlődésének hatása az is, hogy fogyasztásunkat már nem feltétlenül szükségleteink, hanem az elérhetố információk, az adott termékrôl vagy szolgáltatásról alkotott kép határozza meg. Ilyen gazdasági-társadalmi környezetben megítélésem szerint egyre nagyobb jelentôsége van a személyes kapcsolatoknak, az értéken alapuló közösségi hálózatoknak. ${ }^{12}$

Érdekes elméletet fogalmazott meg Karinthy Frigyes Láncszemek címú novellájában 1929-ben (!). ${ }^{13}$ E szerint két teljesen ismeretlen ember között legfeljebb öt, egyenként személyes ismeretséget jelentô személyen át közvetett kapcsolatot lehet találni. A sejtést azóta a gyakorlat (pl. Facebook) és matematikai modellek is igazolták. Utóbbit Stanley Milgram kisvilág-kísérlete alapozta meg 1967-ben, mely során arra a következtetésre jutott, hogy két távoli pont (személy) között átlagosan 5,5 lépésnyi (személyes ismeretségen keresztüli) távolság van. A kisvilág-tulajdonság lényege, hogy hálózatot szimbolizáló gráfban vannak népszerú és kevésbé népszerú (csúcsból kiinduló élek száma alapján) csomópontok, amelynek eredménye, hogy a relatív nagyszámú csúcsok közötti átlagos távolság mégis kicsi. A kisvilág-tulajdonságra építô modelleket pl. az internet optimális felépítésének vizsgálatában, de személyes kapcsolatok elemzésében is egyre inkább eredményesen hasznosítják.

Ha a társadalmat az egyének hálózataként fogjuk fel, és minden emberi kapcsolatot az adott csúcsokat összekötô élként, a kirajzolódó gráf egyfajta képet rajzol ki. Ez a kép sok módon értelmezhetô, de számomra az a legizgalmasabb, hogy a teljes gráfhoz képest mekkora részt tesznek ki az olyan kapcsolatok, amelyek kölcsönösen elônyösek $^{14}$ (vagy az adott szereplók percepciójában ez így jelenik meg). Ezen belül is azok, amelyek nem üzleti vagy hatalmi motivációjúak; másképp fogalmazva, nem az önérdek jelenti az elsố számú motívumot. Persze ennek mérése komoly nehézségekbe ütközhet, hiszen már a társadalmi tôke mérését illetôen sincs egyetértés a kutatók között.

A társadalmi kapcsolatok minôsége, irányultsága és erôssége alapján megkülönböztethetôk az alábbi dimenziói (Tóth, 2005:22):

- összetartó társadalmi tôke, melyet az erôs kötôdések jellemeznek pl. családi vagy etnikai alapon (bonding);

- összekötô társadalmi tôke, amely lazább hálót jelent, de csoporthatárokon átível, integratív jellegú (bridging);

- összekapcsoló társadalmi tôke az elkülönülő struktúrák, pl. a civil társadalom és a kormányzat közötti együttmúködést jellemzi (linking). 


\section{ÖSSZEGZŐ GONDOLATOK}

Az utóbbi évtizedekben megmutatkozó válságok (90-es évek végi orosz, kézezres évek végi jelzálogpiaci válság) nem csak a gazdasági életben mutatkoztak meg. Más folyamatokkal (globális felmelegedés, migráció, információs technológia, CETA/TTIP, cégméretek) együttesen a társadalmi szervezôdés minden szintjén kezdenek látszani olyan törésvonalak, amelyeknek kezelését a szokványos eszközökkel nem lehet megvalósítani. Megszokott, hagyományos gazdaságpolitikai jelzôrendszereink nem képesek elôre jelezni a közelgó veszélyeket, és számos esetben már ismert, korábban is felmerült probléma nyomán következnek be hasonló eseménysorok. Eközben az állami eszközrendszer nem igazán hatásos, mert egyre inkább olyan globális problémák jelennek meg a lokalitásban, amelyeket egy-egy ország nem (sốt akár országcsoport sem) képes kezelni. A TNC-k határokon átívelô hálózatai egyre inkább kezükbe veszik az irányítást - egyelőre állami közremúködéssel.

Ilyen kihívások közepette is található azonban olyan ellenszer, amely képes - apró lépéseken keresztül - elôbb az egyén, majd csoportok szintjén, késôbb pedig kiterjedtebb módon a kívánatos irányba terelni életünket. A személyek szerves - tehát nem felületes online kommunikáción alapuló - hálózatai, egymás értékeinek tiszteletben tartása, figyelembevétele és a közösségek lehetnek a jövôben a boldogulás alapjai. Ezek a hálózatok azonban nem lehetnek sem felülrôl szervezettek, sem rendszerezettek. Nem teremthetốk, csak maguktól, gondolkodásra és problémamegoldásra fókuszáló egyének öntevékenysége által jöhetnek létre. Mint minden kulturális változás, ez sem történik meg egyik pillanatról a másikra (külön erốteljes sokkhatást nem feltételezve), előfeltételeinek megteremtését viszont az állam támogathatja, nem csupán anyagi értelemben. A kitartó és kellốn elôrelátó, akár évtizedes távlatban gondolkodó és tervezô szakpolitikák összehangolásának azonban nagy akadálya a jelenlegi nyugati demokráciákban szokásos politikai ciklikusság, amely megnehezíti az ilyen programok kialakítását. A szélesebb társadalmi konszenzus megteremtéséhez ezért vagy rendkívüli politikai bölcsesség, vagy olyan körülmények szükségesek, melyekbôl következhet a hatalomgyakorló viszonylagos változatlansága. Harmadik útként pedig érdemes fontolóra venni azt is, hogy új keretek létrehozásával a ciklusoktól függetleníthetô célok megvalósítása és finanszírozása is teret kaphasson.

\section{JEGYZETEK}

1871. évi XVIII. törvénycikk a községek rendezéséről, 22. § c).

2 A Népjóléti Minisztérium 1932-ben megszúnt, majd 1944-ben az Ideiglenes Nemzetgyúlés újra létrehozta.

3 1927. évi XXI. törvénycikk a betegségi és baleseti kötelezó biztosításról.

4 Magyar Dolgozók Pártja 1948. júniusi programja (részlet).

5 A lehatárolás önmagában is furcsa, miután elôbbiek sui generis jogalanyok, a nonprofit gazdasági társaságok nem önálló cégformát takarnak. Lásd Auer et al., 2011:44.

6 Országos Bírósági Hivatal, Civil Szervezetek Névjegyzéke, www.birosag.hu.

7 KSH, STADAT táblák, 3.2.1.2. A regisztrált gazdasági szervezetek száma - GFO’11. 


\section{Szablics Bálint: Quo vadis, avagy a nemzetgazdaság és társadalom fejlódésének...}

8 A KSH a Gazdasági Formák Osztályozása alapján sorolja be a szervezeteket, amely során pl. a közalapítványokat, nonprofit gazdasági társaságokat is a nonprofit kategóriában jeleníti meg.

9 A KSH által használt „önkéntes” fogalom nem egyezik a közérdekú önkéntes segítô fogalmával, amely egy szúkebb kört jelöl.

10 Ennek 31,3\%-a állami, 35\%-a magántámogatásból, 23,2\%-a alaptevékenységbốl, 8,8\%-a gazdasági-vállalkozási tevékenységbôl, 1,6\%-a egyéb forrásból származott 2014-ben.

11 Pl. a Facebook és más közösségi oldalak lehetôvé teszik a gyors és olcsó kommunikációt, de közben az emberek egyre kevésbé használják ezt tartalmas dolgok közvetítésére. Számos, az emberi kapcsolatok fejlôdésére hatástalan, lényegtelen információval árasztjuk el egymást, de legfốképp az ezen információkból üzleti hasznot kovácsoló mamutcégeket.

12 Hasonló gondolatokat fogalmazott meg prof. dr. Lentner Csaba a már idézett Rendszerváltás és pénzügypolitika c. könyvében, amikor a rendszerváltozás következményei kapcsán felhívta a figyelmet a polgárosodás helyett megvalósuló menedzseresedés problémájára (Lentner, 2005).

13 Karinthy Frigyes: „Ki kérdezett?” Címszavak a Nagy Enciklopédiához, http://mek.oszk.hu/07300/07367/ html/01.htm.

14 Ez a fajta játékelméleti megközelítés érvényesül a bizalmi kapcsolatok kialakulásában is.

\section{FELHASZNÁLT IRODALOM}

Auer Ádám et al. (2011): Társasági jog. Lectum Kiadó, Szeged.

Csath Magdolna (2014): Versenyképesség. In: Közgazdaságtan. Társadalom-gazdaságtan, makroökonómiai alapok. Nemzeti Közszolgálati Egyetem, Budapest.

Fülöp Sándor (2006): Egyesületek bírósági nyilvántartásba vételi gyakorlata. EMLA Egyesület, Budapest.

Kuti Éva (1998): Hívjuk talán nonprofitnak... Nonprofit Kutatócsoport, Budapest.

Kuti Éva - Marschall Miklós (1991): A nonprofit szektor fogalma. Egy definíciós vita, és ami mögötte van. Esély, 3. évf., 1. sz., 61-69.

Lentner Csaba (2005): Rendszerváltás és pénzügypolitika. Akadémiai Kiadó, Budapest.

Sipos Katalin (2003): Európai Unió: Civil társadalom - nem kormányzati szervezetek - Konvent. Állam- és Jogtudomány, 44. évf., 3-4. sz., 267-290.

Tokaji Károlyné (szerk.) (2016): Nonprofit szervezetek Magyarországon 2014. KSH, Budapest.

Tomka Béla (2003): A jóléti kiadások alakulása Magyarországon nemzetközi összehasonlításban 1918-1990. Statisztikai Szemle, 81. évf., 1. sz., 52-69.

Tóth István György et al. (2005): A társadalmi tôke növelésének lehetôségei fejlesztéspolitikai eszközökkel. Tárki, Budapest. 